\title{
Vegetated roofs in boreal climate support mobile open habitat arthropods, with differentiation between meadow and succulent roofs
}

\author{
Kukka Kyrö ${ }^{1}$ (D) D. Johan Kotze ${ }^{2}$ (D) $\cdot$ Małgorzata Anna Müllner ${ }^{1}$ (D) Sanja Hakala ${ }^{3}$ (D) Elöd Kondorosy $^{4}$. \\ Timo Pajunen $^{5}$ • Ferenc Vilisics ${ }^{6}$. Susanna Lehvävirta ${ }^{1,7}$ (D)
}

Published online: 30 April 2020

(C) The Author(s) 2020

\begin{abstract}
Vegetated roofs are hoped to benefit urban wildlife, yet there are few empirical results regarding the conservation potential of such roofs. In this paper, we focus on arthropods on vegetated roofs. We vacuum sampled 17 succulent, meadow or succulentmeadow roofs, in Helsinki, Finland, and used order to species level information together with trait data to describe the communities. We evaluated the importance of biophysical roof characteristics on shaping arthropod assemblages to provide information concerning roof designs that promote rich arthropod fauna. Arthropod communities differed between the three roof types and the influence of roof variables varied between and within arthropod orders. The main local drivers of arthropod abundance across the individually analysed taxa were roof height and vegetation, with mainly positive effects of height (up to $11 \mathrm{~m}$ ) and litter cover, and mainly negative effects of grass cover. Based on trait data from true bugs, spiders and ants, the roofs consisted mainly of common dispersive species that are generalist feeders and associated with dry open habitats or have wide habitat tolerance. We found one true bug species new to the country and assume that it arrived with imported vegetation. Based on these findings, vegetated roofs of varying height and size benefit common generalists and fauna of open dry habitats, but seem to lack rare native specialists and may introduce non-natives if imported plant material is used. Because the responses to vegetation characteristics are taxon-specific, high diversity of roof vegetation types would benefit arthropod conservation.
\end{abstract}

Keywords Arthropods · Insects · Functional traits · Green roof · Nature-based solutions · Urban ecology

\section{Introduction}

Urbanization threatens biodiversity at multiple spatial scales (Grimm et al. 2008; Seto et al. 2012), with a major driver of

Electronic supplementary material The online version of this article (https://doi.org/10.1007/s11252-020-00978-4) contains supplementary material, which is available to authorized users.

Kukka Kyrö

kukka.kyro@helsinki.fi

1 Faculty of Biological and Environmental Sciences, Ecosystems and Environment Research Programme, University of Helsinki, P.O. Box 65, 00014 Helsinki, Finland

2 Faculty of Biological and Environmental Sciences, Ecosystems and Environment Research Programme, University of Helsinki, Niemenkatu 73, FI-15140 Lahti, Finland

3 Faculty of Biological and Environmental Sciences, Organismal and Evolutionary Biology Research Programme, University of Helsinki, Helsinki, Finland local biodiversity loss being the conversion of natural and semi-natural areas to urban land use characterized by impervious surfaces (McKinney 2002). Loss of habitat due to urbanization is substantial: between 1992 and 2000, urban

4 Department of Animal Science, Georgikon Faculty, University of Pannonia, 16. Deák F. Str, H-8360 Keszthely, Hungary

5 Finnish Museum of Natural History LUOMUS, University of Helsinki, Helsinki, Finland

$6 \quad$ Helsinki, Finland

7 Department of Landscape Architecture, Planning and Management, University of Helsinki, Swedish University of Agricultural Sciences, Slottsvägen 5, POB 58, Alnarp SE-23053, Sweden 
growth accounted globally for $16 \%$ of the direct loss of natural habitats $\left(190000 \mathrm{~km}^{2}\right)$ and the pace is projected to accelerate (McDonald et al. 2018). Despite the negative environmental impacts related to urbanization, it also provides opportunities for conservation (Dearborn and Kark 2010). In order to mitigate several negative environmental effects of urbanization, including biodiversity loss, there is a growing interest towards nature-based solutions (NBS), i.e. living solutions inspired and supported by nature that increase sustainability and resilience of societies (European Commission 2015; Maes and Jacobs 2017).

Vegetated roofs (i.e. roofs covered with vegetation, see Kotze et al. 2020) is an example of NBS that can provide a variety of environmental, economic and social benefits (Francis and Lorimer 2011; Nurmi et al. 2016). Particularly, roofs with nearly self-sustaining vegetation are rapidly increasing in number in modern cities. Plant assemblages of self-sustaining roofs in temperate and cooler climates typically consist of mosses, succulents, forbs and/or grasses adapted to dry conditions and low nutrients levels.

Studies on the flora and fauna of self-sustaining vegetated roofs have shown that they are able to support a wide variety of plants (Madre et al. 2014; Gabrych et al. 2016) and animals, especially invertebrates (Madre et al. 2013; Braaker et al. 2017; Pétremand et al. 2018), and may increase habitat connectivity (Braaker et al. 2014). Self-sustaining vegetated roofs are specifically hoped to support open habitat species as they are rarely planted with trees or bushes. For example, in Basel, Switzerland, vegetated roofs have been established to mimic local open natural habitats, such as riverbanks and dry meadows (Brenneisen 2006).

Vegetated roof arthropod communities are characterized by common, mobile, open habitat generalists. Yet, stenotopic species and even rare and endangered species of xeric habitats are found (Brenneisen and Hänggi 2006; Kadas 2006; Madre et al. 2013; Kyrö et al. 2018; Pétremand et al. 2018), increasing the attractiveness of vegetated roofs as tools to mitigate habitat loss from urbanization.

A conceptual framework for assessing the value of vegetated roof habitats for arthropods lies in species diversity theories of fragmented environments (MacArthur and Wilson 1967; Rosenzweig 1995; Leibold et al. 2004). The value of vegetated roof habitats is expected to vary according to biophysical characteristics of the roof, referred to here as roof characteristics. The main roof characteristics to drive arthropod diversity and abundance are suggested to be roof size, vegetation, substrate quality and quantity, roof age and connectivity, but the strength and direction of these effects vary for different taxa (Madre et al. 2013; Braaker et al. 2014; Kyrö et al. 2018; Ksiazek-Mikenas et al. 2018; Pétremand et al. 2018). Furthermore, basic community level approaches show that roof arthropod communities are different from ground level ones. Both species richness and abundance tend to be lower on roofs compared to ground level open habitats (Colla et al. 2009; Tonietto et al. 2011; MacIvor and Lundholm 2011; Braaker et al. 2017), but the lower species diversity does not mean a decreased trait diversity (Braaker et al. 2017) nor degradation of ecosystem services provided by arthropods (Ksiazek et al. 2012).

Despite progress in depicting vegetated roof arthropod communities, we are far from understanding the habitat value of different kinds of roofs for arthropods. Existing knowledge concentrates on a few taxa, i.e. carabid beetles (Carabidae), spiders (Araneae) and pollinating insects from the group Aculeata, often originating from small case studies with 2-9 roofs and descriptive statistics. Most analyses are performed at the family level, grouping species with highly variable ecologies, while Kyrö et al. (2018) pointed out that species from the same taxonomic group may show opposite responses to roof characteristics and mask each other's effects if pooled. Thus, to be able to reveal possible variation in response trends, we need information on how roof characteristics drive abundances of individual species.

Most vegetated roof studies are conducted in temperate climates. Although the plant assemblages roughly resemble the roofs we studied, with either succulent or forb and grass dominated vegetation, we cannot make direct inferences from temperate areas on arthropod communities that vegetated roofs host in boreal climates. In boreal climates, the roof fauna may be shaped by a dependency on frequent recolonizations compared to temperate climates, because in addition to drying out during hot summers, substrates freeze with varying snow cover during winter, which likely hinders arthropod overwintering. Moreover, data on arthropods' functional traits remain scarce. Traits are important for understanding the processes that shape communities (McGill et al. 2006; Cadotte et al. 2011; Gagic et al. 2015). Yet, we lack knowledge on variation in species traits between different kinds of vegetated roofs.

In this study, we describe epigeal arthropod communities on three types of vegetated roofs: (1) meadow roofs, (2) succulent roofs and (3) succulent-meadow roofs. We investigate the communities from both taxonomic and trait perspectives to evaluate the habitat value of vegetated roofs for arthropods in a boreal climate and to provide recommendations for roof design, i.e. combinations of roof characteristics that contribute to arthropod conservation by promoting a rich fauna as proposed by Williams et al. (2014).

We examine the responses of arthropods to roof characteristics from data identified to order or suborder and from species data that include true bugs (Hemiptera: Heteroptera), spiders (Araneae) and ants (Hymenoptera: Formicidae). We did not have the expertise to identify all collected arthropod groups to species level, but we chose the individually analysed taxa to present arthropods from different feeding groups and with varying dispersal strategies. In addition, we apply data 
from morphological and ecological species traits of true bugs and spiders to describe trait characteristics for the roof fauna.

We investigate how these taxa respond to differences in vegetation, substrate, and roof age, size and height. Specifically, we ask whether and how the biological and physical roof characteristics described above shape (i) arthropod communities; (ii) the abundances of specific taxa, and (iii) communities' trait composition. While few precise hypotheses can be formulated when taxa with varying ecologies are grouped, we expect (i) roof characteristics to shape arthropod community composition even in data grouped to order/ suborder level. Derived from the theoretical framework of fragmented environments, we expect (ii) to find a positive effect of roof size on abundance and richness and predict the effect of roof height to be negative. Based on results from vegetated roofs and other fragmented urban habitats, we expect (iii) a negative correlation between roof age and abundance (Bolger et al. 2000; Kyrö et al. 2018). Furthermore, we hypothesize that (iv) trait composition of the arthropod communities, including traits related to dispersal, feeding and habitat affinition, will vary according to roof characteristics that describe vertical isolation and roof vegetation (Braaker et al. 2017). Finally, related to i) - iv), we expect (v) herbivores to be connected with vegetation characteristics, but predatory arthropods to respond stronger to roof size, height and age (Kruess and Tscharntke 1994; Bolger et al. 2000; van Noordwijk et al. 2015).

\section{Materials and Methods}

\section{Study area}

We investigated 17 vegetated roofs in the city of Helsinki $(60.17 \circ \mathrm{N}, 24.94 \circ \mathrm{E})$, Finland (Table 1). Helsinki has a southern boreal climate with a mean annual temperature of ca. $6^{\circ} \mathrm{C}$, annual precipitation of 650-700 $\mathrm{mm}$ and snow cover of 115 days on average (in 1981-2010, Finnish Meteorological Institute 2018). Although not common in Helsinki, vegetated roofs are increasing in number, with a total cover of ca. 4 ha in 2013 (Helsingin seudun ympäristöpalvelut 2016). In comparison, the ground level green space of Helsinki includes 537 ha of various types of meadows (Saukkonen 2011), the closest vegetation analogues to the kinds of roofs we studied.

\section{Study sites and arthropod sampling}

We surveyed a selection of roofs from Gabrych et al. (2016) that were of different size, height and age and had varying vegetation (Table 1). Six of them were succulent roofs with $97 \%$ of the vegetation cover consisting of succulents and mosses. Seven were meadow roofs with forb and grass dominated vegetation. Four were dominated by succulents and mosses, but included $3 \%$ of forbs and grasses, referred to as succulent-meadow roofs. We collected arthropods with a D-Vac vacuum insect collector, model 122 (Rincon-Vitova Insectaries) with a circular nozzle (Dietick et al. 1959). We vacuumed randomized sampling spots with an area of $0.79 \mathrm{~m}^{2}$ (a circle with a radius of $0.5 \mathrm{~m}$ ) for $30 \mathrm{~s}$. All sampling spots were placed at least $1 \mathrm{~m}$ apart and $1 \mathrm{~m}$, or as far as possible, from the roof edge. The number of samples per roof was adjusted to roof size $a\left(\mathrm{~m}^{2}\right.$, measured as the area of vegetation on the roof) following the formula $n=\sqrt{a \cdot 0.5}$. Consequently, the smallest roof $\left(13.8 \mathrm{~m}^{2}\right)$ had 3 sampling points and the largest roof $\left(350 \mathrm{~m}^{2}\right)$ had 13 .

We sampled all roofs monthly from May to August (2012). The arthropods were stored in $70 \%$ ethanol and sorted to order, suborder or family level, excluding soil fauna (Acari and Collembola). Adult spiders, true bugs and ants were sorted to species level. Juvenile spiders and true bugs were identified to the lowest possible taxonomic level (genus, family, or species). Vegetation data and roof characteristics were obtained from Gabrych et al. (2016) (Table 1).

\section{Species traits and roof characteristics}

We collected trait data for true bugs and spiders (see Supplementary Material, Tables S1 and S2), and used nine hypothetically important roof characteristics to explain arthropod abundance and species richness in the statistical analyses: roof size $\left(\mathrm{m}^{2}\right)$, height $(\mathrm{m})$, age (years since establishment), substrate depth $(\mathrm{cm})$, the number of plant species (excluding mosses), and \% covers of forbs, grasses, bare ground and dead plant material (litter and standing dead plants). We checked roof variables for multicollinearity using variance inflation factors (VIF) (Zuur et al. 2010). We set the limit of VIF at 5 allowing for intermediate levels of collinearity, but based our choice of variables also on biological knowledge: among those with high VIF values, we retained vegetation variables and excluded age and substrate depth from the analysis as we assumed the latter ones to be reflected in the vegetation that should be a more proximate predictor for arthropods. Furthermore, we excluded bare ground because it had high VIF-values and its cover was low $(<10 \%)$ on most roofs (Table 1). After exclusion, we had six roof variables: size, height, number of plant species, and covers of forbs, grasses and dead plant material.

\section{Statistical analyses: community composition, abundance and species richness}

We used R version 3.5.0 (R Development Team 2018) for all statistical analyses. We pooled the arthropod data roofwise to describe community composition and to evaluate 
Table 1 Summary of roof characteristics

\begin{tabular}{lrrrr}
\hline & Mean & Median & Minimum & Maximum \\
\hline Size $\left(\mathrm{m}^{2}\right)$ & 103 & 41 & 14 & 350 \\
Age (years) & 10 & 9 & 3 & 21 \\
Height (m) & 4 & 3 & 1 & 11 \\
Substrate depth (cm) & 11 & 11 & 3 & 24 \\
Grass cover $(\%)$ & 7 & 5 & 0 & 22 \\
Forb cover $(\%)$ & 15 & 9 & 0 & 44 \\
Succulent cover $(\%)$ & 35 & 28 & 0 & 84 \\
Moss cover $(\%)$ & 15 & 12 & 1 & 38 \\
Dead plant material cover $(\%)$ & 29 & 33 & 1 & 66 \\
Bare ground cover $(\%)$ & 6 & 3 & 0 & 27 \\
Total vegetation cover (sum of all vegetation layers) $(\%)$ & 77 & 69 & 45 & 122 \\
Number of plant species / roof & 16 & 18 & 3 & 29 \\
\hline
\end{tabular}

the role of the six abovementioned roof characteristics plus the categorical variable roof type (three levels: meadow, succulent and succulent-meadow), using non-metric multidimensional scaling (NMDS). We standardized the numbers of individuals per $100 \mathrm{D}$-vac suctions, and set the number of dimensions to three, applied stable solutions from random starts and the Bray-Curtis dissimilarity index (metaMDS, vegan package 2.5.-2; Oksanen et al. 2018). We analysed group level data (orders, suborders and ants separated from other Hymenoptera and for spiders and true bugs also family level data; Fig. 1). We treated adult and juvenile data for true bugs and spiders separately in all analyses. For true bugs, we used juvenile data only at the suborder level, because part of the juveniles was not identified to lower levels. For spiders, we included juvenile data (separated from adult data) also in the analyses of lower taxa.

We used a multi-response permutation procedure (MRPP) (McCune et al. 2002) to test if communities differed between the roof types (meadow, succulent, succulent-meadow). Similar to the NMDS's, we used standardized abundances from arthropod groups and true bug and spider families, and performed pairwise comparisons for all roof types. We used $\mathrm{T}$ values to describe the separation between groups and p-values for the statistical significance of each separation.

We modelled the responses of arthropod groups to roof variables with generalized linear mixed models (GLMM, function glmer, lme4 package) (Bates et al. 2015). The response variable (number of individuals or species) was modelled following a Poisson error distribution, applying an individual level random effect to control for overdispersion (Harrison 2014). We accounted for sampling effort by using log-transformed number of samples per site as an offset (Kotze et al. 2012). As some of the roofs shared the same address, we included site as a random term to remove pseudoreplication and to allow for site-specific random variation. We centered the predictor variables to zero mean and unit variation to improve model performance (Schielzeth 2010). Based on p- and AICcvalues (details of the analyses: Supplementary material S3), we performed model selection until all variables had p-values $<0.2$ and validated the final model by visually examining residual plots. We used the $\mathrm{p}<0.2$ criterion to retain information concerning potentially interesting variables for meta-analysis and hypothesis creation for further research, and to reduce publication bias against findings with $p>0.05$ (Amrhein et al. 2017).

After analyzing group level data, we ran similar GLMMs with spider and true bug species, families and genera. Analyses at higher taxonomic levels were performed without the individually analyzed lower taxa (Fig. 1). For the number of species of true bugs and spiders, we applied the GLMMs without singleton data, the offset term and the individual level random effect.

Since both roof age and substrate depth may shape arthropod communities (Brenneisen 2006; KsiazekMikenas et al. 2018; Kyrö et al. 2018), we investigated their effects by adding them in the GLMMs after model selection (as we could not initially include them due to collinearity) (Supplementary material S3). Finally, as some studies suggested total vegetation cover to be important in explaining arthropod abundance (Schindler et al. 2011; Salman and Blaustein 2018), because it affects roof temperature and moisture, we explored the effect of vegetation cover by adding it to the best final model (Supplementary material S3).

We could use the trait data only for descriptive purposes, as the data were not adequate for statistical analyses that combine RLQ and fourth-corner methods: the power of the analysis that detects connections between traits and roof characteristics was weak and, thus, unreliable (Dray and Legendre 2008; Dray et al. 2014). 
Fig. 1 Description of statistical analyses: NMDSs were performed at group (a) and family (b) levels, GLMMs at group (c) and from species to genus and family levels (d). AD = adult, $\mathrm{JUV}=$ juvenile

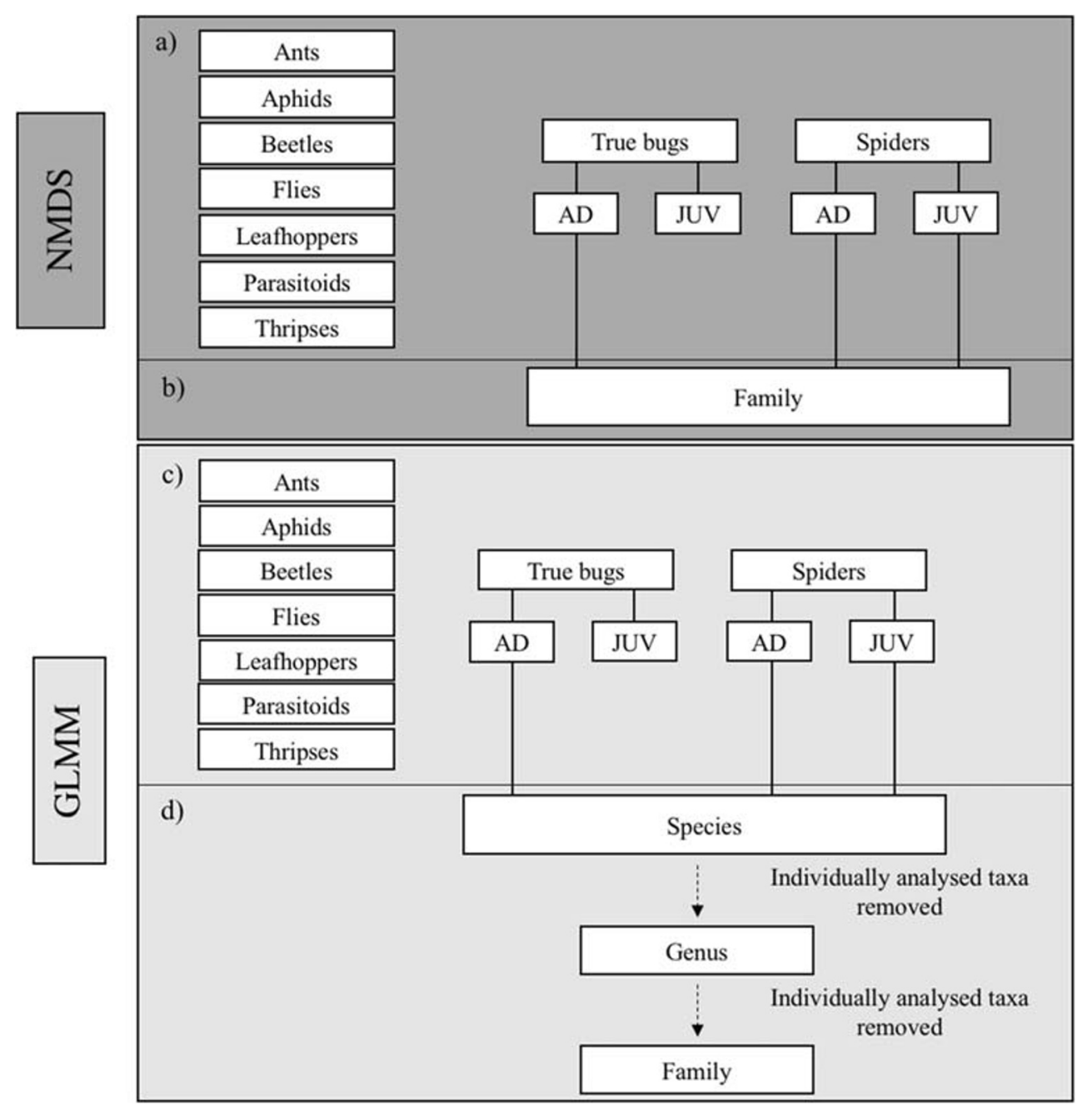

\section{Results}

We collected 9180 arthropods belonging to six orders: Araneae, Hemiptera, Coleoptera, Diptera, Thysanoptera and Hymenoptera. Hemiptera were further divided into true bugs, leafhoppers (Auchenorrhyncha) and aphids (Sternorrhyncha), and Hymenoptera into ants (Formicidae) and parasitoid wasps (Apocrita: Parasitica). We also collected a few individuals from orders Lepidoptera, Neuroptera, Opiliones and Psocoptera, and Hymenoptera belonging to the group Aculeata, but they were not analysed due to low numbers. The most abundant group was flies (4484 individuals), followed by spiders (1050, including juveniles), true bugs (1336 incl. juveniles) and parasitoids (768 individuals) (Supplementary material, Fig. S4).

The ordinations showed that vegetation characteristics and roof height shaped arthropod communities in the group level analysis (Fig. 2a, Supplementary material, Table S5). Herbivores feeding solely on forbs and grasses (aphids and leafhoppers) were abundant on meadow roofs, whereas predators (spiders) and herbivores that have a more varying diet (true bugs) were abundant on succulent roofs (Fig. 2a). True bug community composition was related to vegetation characteristics (Fig. 2b), while spider communities were shaped by vegetation and roof size and height (Fig. 2c).

MRPP results showed that arthropod communities differed between all roof types (meadow vs. succulent: $\mathrm{T}=-5.94, \mathrm{p}=$ 0.002 , meadow vs. succulent-meadow: $\mathrm{T}=-4.41, \mathrm{p}=0.002$, succulent vs. succulent-meadow: $\mathrm{T}=-4.41, \mathrm{p}=0.006$, where a more negative $T$ value indicates greater separation). True bug communities differed between meadow and succulent roofs $(\mathrm{T}=-4.02, \mathrm{p}=0.005)$ and succulent and succulentmeadow roofs $(\mathrm{T}=-1.99, \mathrm{p}=0.005)$, but not between meadow and succulent-meadow roofs $(T=0.62, p=0.680)$. Spider communities did not differ between the roof types (meadow vs. succulent: $\mathrm{T}=-0.51, \mathrm{p}=0.235$, meadow vs. succulentmeadow: $\mathrm{T}=-0.38, \mathrm{p}=0.312$, succulent vs. succulent-meadow: $\mathrm{T}=-0.60, \mathrm{p}=0.207$ ).

The effects of roof characteristics on abundance varied between and within taxonomic groups (Table 2; Fig. 3). 

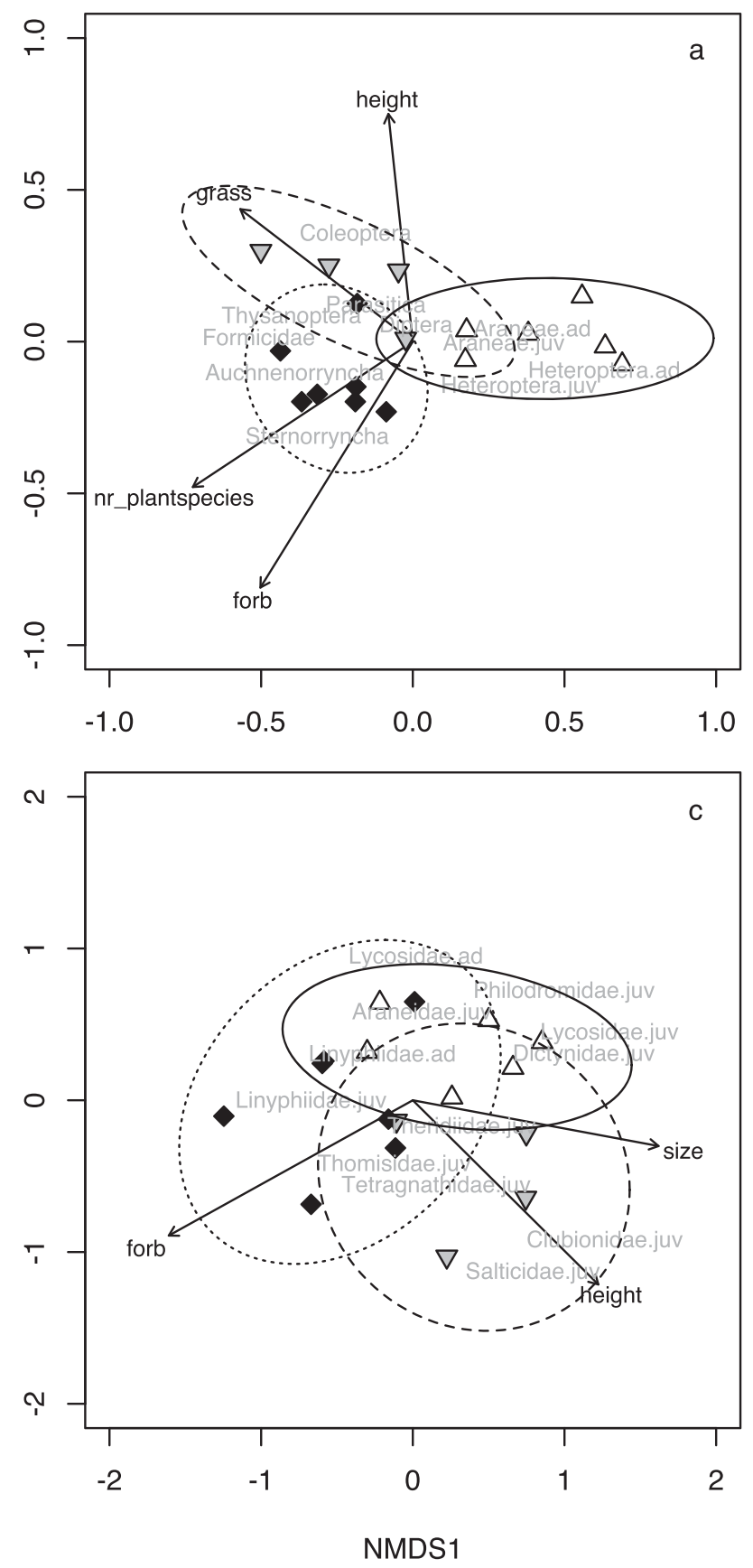

Fig. 2 NMDS ordination plots of the roofs (symbols) and (a) all arthropods, (b) true bug families, (c) spider families. Arrows present roof variables with statistically significant $(\mathrm{p}<0.05)$ correlations to ordination and show the strength and direction of increasing gradient. The ellipses

Roof height and vegetation variables frequently remained in the final GLMMs, while roof size was rarely retained. Height, dead plant material and total vegetation cover had mainly positive effects on abundances, while the effects of roof size, grass cover and number of plant species were mainly negative, and the effects of forb cover, age and substrate depth were both positive and negative (Table 2; Fig. 3).

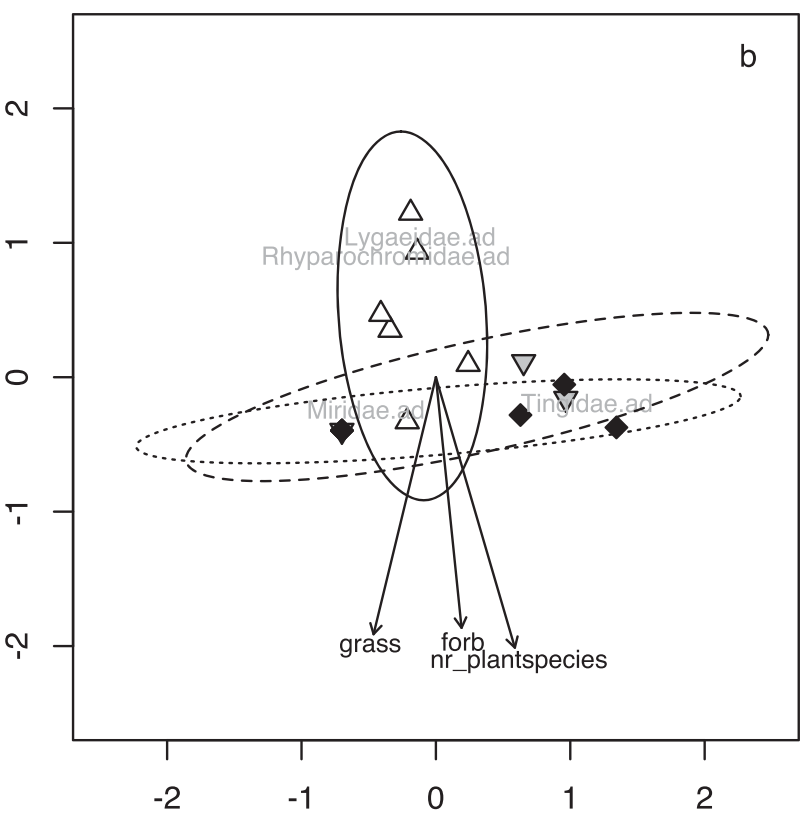

\section{$\triangle$ Succulent \\ $\nabla$ Succulent-meadow \\ $\checkmark$ Meadow}

are based on standard deviation of the points with $95 \%$ confidence intervals: solid line $=$ succulent , dashed line $=$ succulent - meadow, dotted line $=$ meadow, $\mathrm{nr} \_$plantspecies $=$number of plant species

True bug species were negatively affected by grass cover, roof size, age, and vegetation cover, and positively by litter cover. Other roof characteristics had both positive and negative effects, depending on the taxa. The true bugs belonged to 8 families and 31 species (with 493 adults). Trait data showed that these true bugs vary in wing form: 20 species were macropterous and 11 dimorphic (Supplementary material, Table S1). The most abundant families were Miridae (13 
a) Roof height

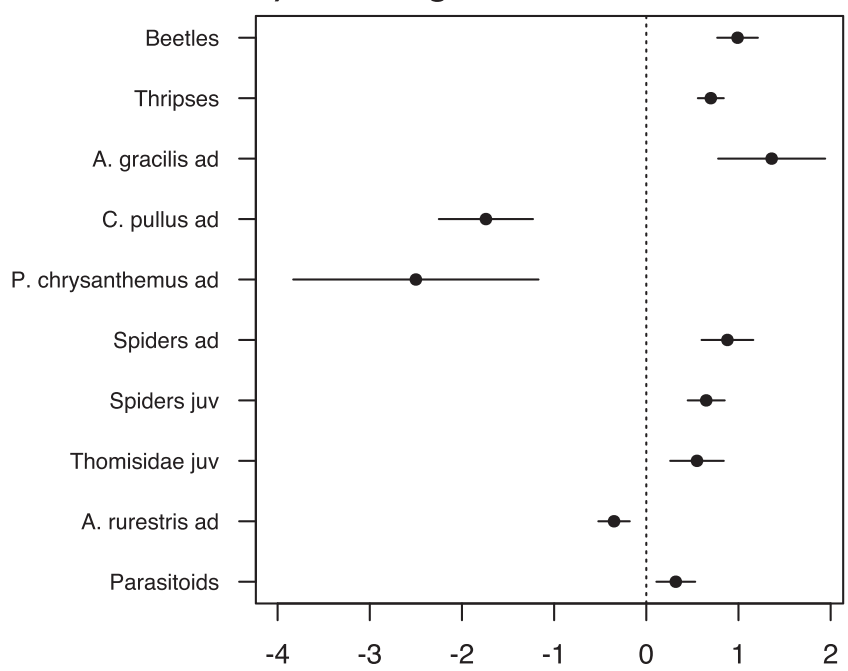

c) Forb cover

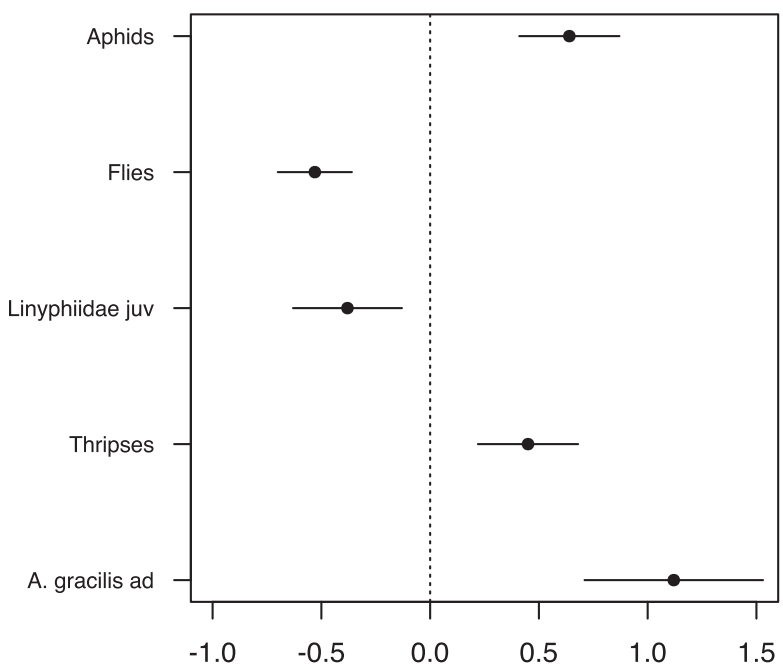

b) Grass cover

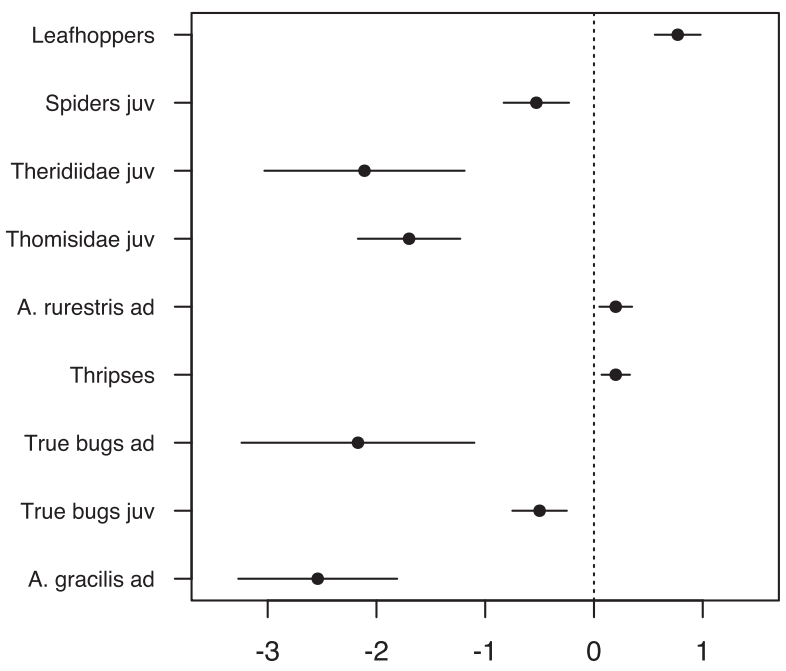

d) Dead plant material

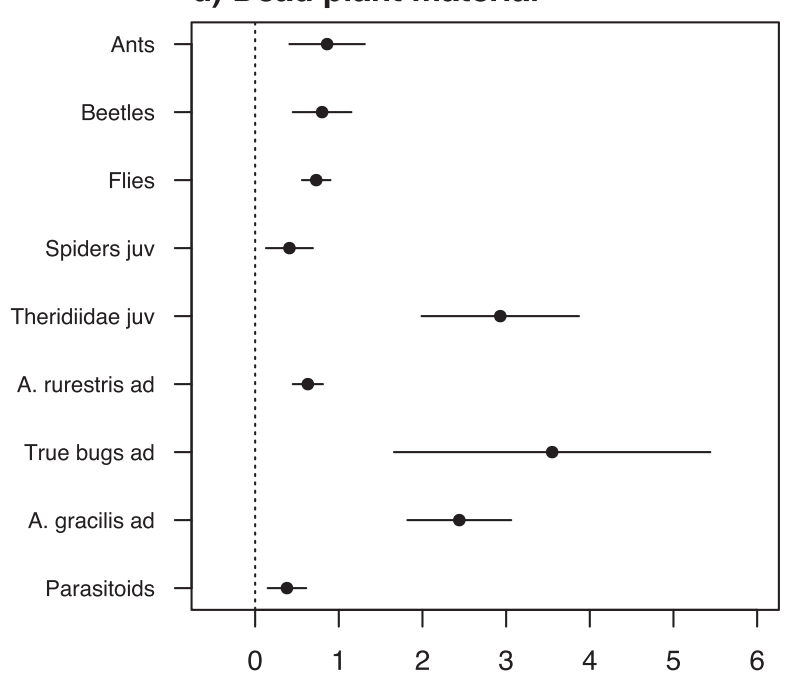

Fig. 3 Responses of arthropod abundances (model coefficients \pm SE) to roof height (a), grass cover (b), forb cover (c) and dead plant material cover (d). Note varying scales for the $\mathrm{x}$-axes. Group responses are based on data where individually analysed species/families have been removed

species, 264 adults) and Lygaeidae (10 species, 137 adults). Among adults, Chlamydatus wilkinsoni was the most abundant species (123 individuals on 5 roofs), but Chlamydatus pullus and Plagiognathus chrysanthemi were most frequent, occurring on 9 roofs (51 and 42 adults in total, respectively). These three species are common generalist herbivores of open dry habitats (Supplementary material, Table S1). With one exception, the species were of least conservation concern (LC) (Hyvärinen et al. 2019): Chlamydatus evanescens had not been recorded in Finland before (Ilpo Mannerkoski, personal communication), and thus lacks status assessment.

Spider abundances were positively associated with dead plant material, total vegetation cover and height (excluding Agyneta rurestris with a negative response to height), and negatively with the number of plant species and substrate depth (Table 2; Fig. 3). $86 \%$ of the spiders (in total 12 families, 23 species) were juveniles. Among adults, Linyphiidae was the most abundant family on every roof. The most abundant species was A. rurestris, a habitat generalist (97 individuals on 14 roofs). Other spider species accumulated just 1-13 adults, on 1-5 roofs and no adults were captured on three small roofs (size: $\left.14-33 \mathrm{~m}^{2}\right)$.

Most of these species share similar dispersal and hunting traits: they balloon frequently and are web-weavers (Supplementary material, Table S2). Furthermore, habitat affinities of the collected spider species vary: they live in open and semi-open habitats, dry and moist environments, and some are thermophilic (Supplementary material, Table S2). We found no rare or endangered spiders. 


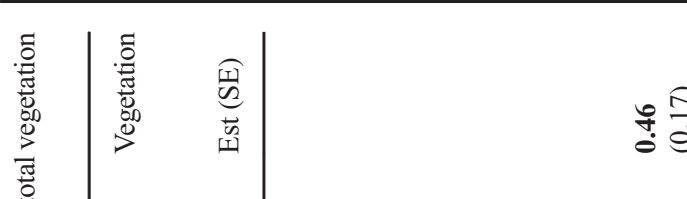

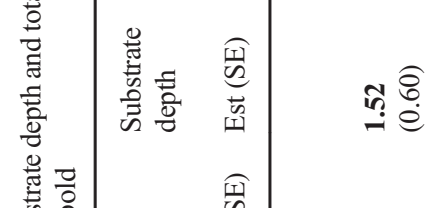

$\frac{1}{5}$

กำ $\frac{\widehat{\sigma}}{9}$

ํํํ

$\infty \frac{\sqrt[5]{4}}{0}$

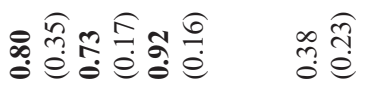

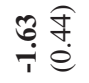

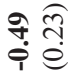

$\stackrel{\Xi}{\stackrel{E}{:}}$

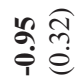

च.

ล̊ํํ

$\stackrel{\infty}{\stackrel{\infty}{0}}$

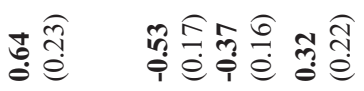

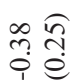

ㅊํㅇ

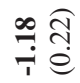

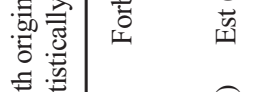

동

กิ

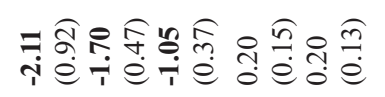

寻

济

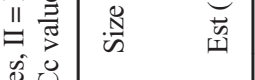

ஸेत సิ

$\hat{i} \frac{\infty}{\dot{e}}$

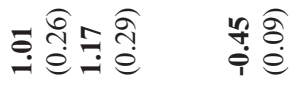

焉

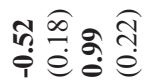

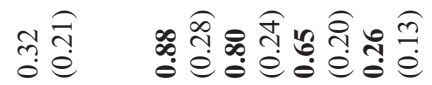

ñ่ำ

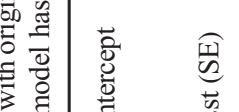

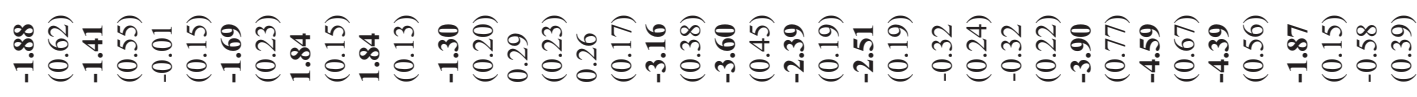

要离

蛋

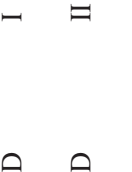

\& $\begin{aligned} & 3 \\ & 2\end{aligned}$

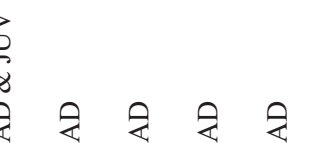

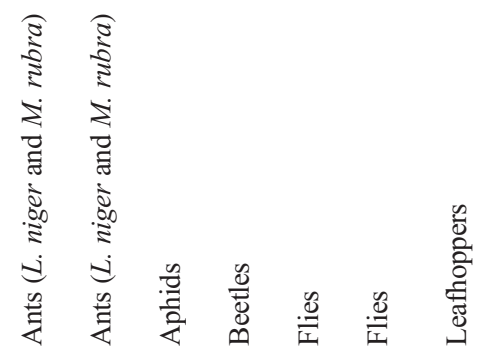
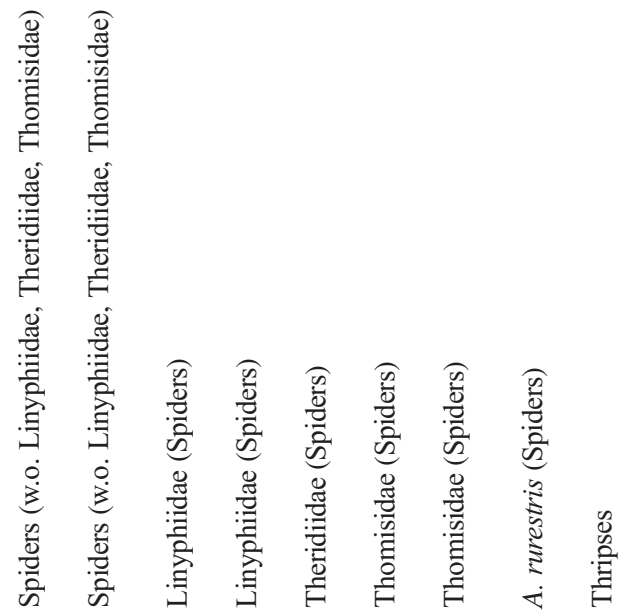


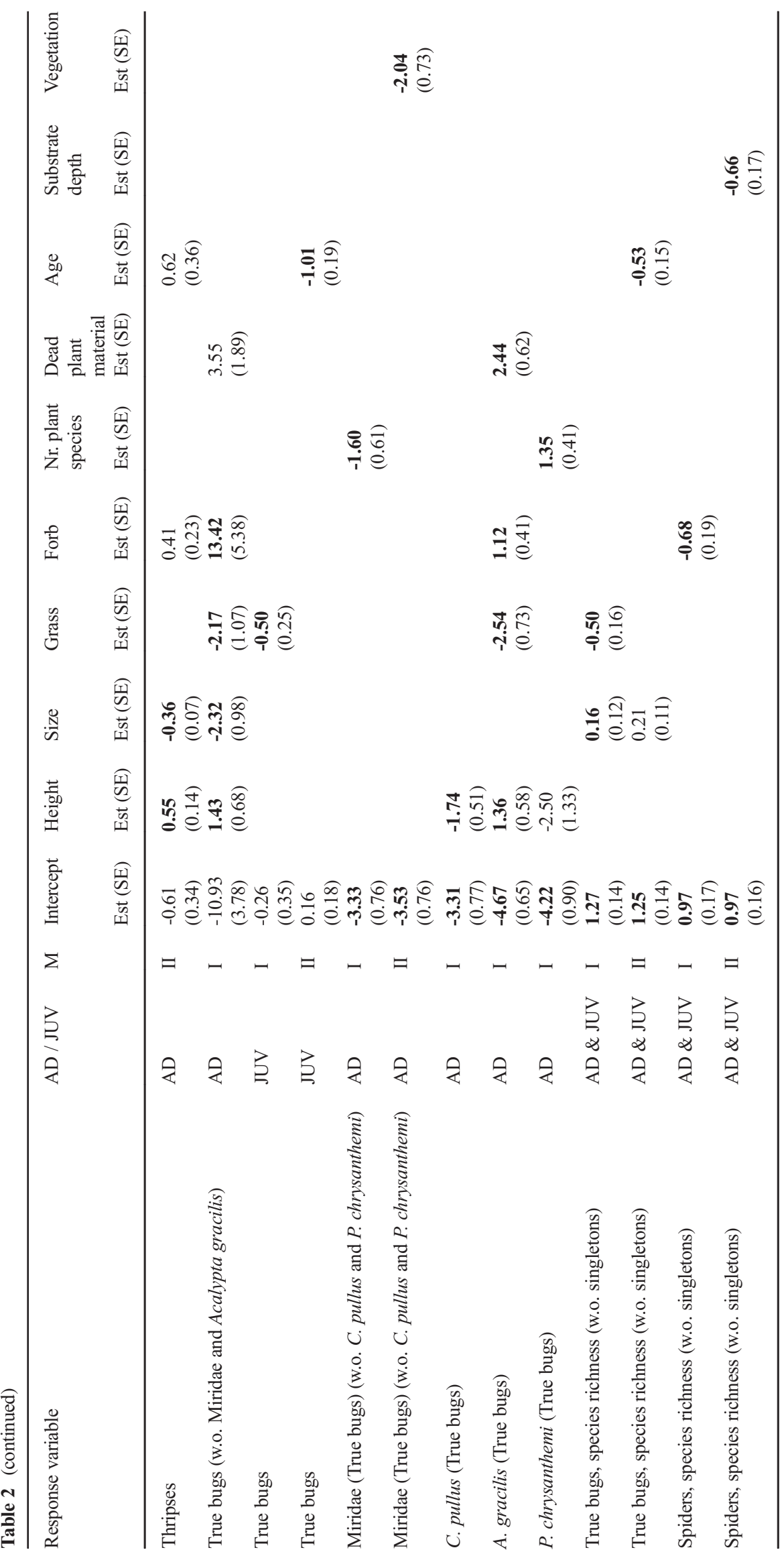


Ant abundance increased with substrate depth and dead plant material (Table 2). The two species that we found, Lasius niger (185 individuals on 13 roofs) and Myrmica rubra (16, on two roofs), are highly dispersive ecological ubiquist pioneers. They are good competitors and forage and prey on a wide variety of food (Collingwood 1979).

\section{Discussion}

\section{Importance of vegetated roofs for arthropods}

We studied arthropod assemblages on different kinds of urban vegetated roofs to evaluate their habitat and conservation value, and to find roof designs that best promote these targets. The main local drivers of arthropod abundance across a variety of urban succulent to meadow roofs were vegetation type and roof height. The roofs hosted mainly common open and semi-open habitat species, lacked species of conservation concern, and may have introduced non-natives. The orders/ suborders we collected from the roofs reflected suction sampling data from urban ground level open habitats (Bolger et al. 2000; Kutschbach-Brohl et al. 2010). Yet, the absence of grasshoppers (Orthoptera) was surprising. The likely explanations are their sensitivity to fragmentation (Appelt and Poethke 1997) and the sampling method we used. The combination of small patch size and isolation from source habitats may prevent grasshoppers from establishing populations on the studied roofs. Moreover, although grasshoppers are better caught with sweep netting compared to vacuum sampling, vacuuming line transects do yield grasshoppers (Doxon et al. 2011), but vacuuming several circle-shaped spots may give these highly visual animals better chances to escape. In summary, we did not find support for arthropod communities on vegetated roofs being species rich or including rare or endangered native species, an argument often applied to promote vegetated roofs. However, the roofs we studied were not specifically built for conservation purpose and may thus lack key qualities that promote habitat provision for arthropods. Thus, it would be interesting to design test roofs specifically for conservation purposes to explore their capacity to attract and support declining, rare and endangered species.

We collected one true bug species new to Finland (C. evanescens), which is widely distributed in Central and Southern Europe and feeds on sedums (Linnavuori 2007). The species has also been found on vegetated roofs in London, where it is classified as nationally rare (Jones 2002). Jones (2002) argued that it had likely arrived with pre-grown imported succulent mats, a probable explanation also for the presence of $C$. evanescens on two of our study roofs. If brought with roof materials, it must have overwintered and reproduced on the roofs several times, as these roofs were three years old.
Previously, vegetated roofs established with prefabricated succulent mats in Helsinki have also been found to host two snail species rare in Finland (Páll-Gergely et al. 2014), and a black fungus gnat species (Diptera, Sciaridae) new to the country (Pekka Vilkamaa, Finnish Natural History Museum, personal communication). Rather than supporting the idea of vegetated roofs as effective tools for arthropod conservation, the presence of these locally rare species raises a concern about species introductions. Imported plant material is globally recognized as a major pathway for invasive insects, and constructed habitats are among the most important outdoor habitat types for alien insect species (Kenis et al. 2007). The risk for species introductions is likely to be higher on roofs that are built using imported prefabricated vegetation mats, compared to roofs established with plug plants and seeds. Yet, as we lack direct evidence on the origins of these species, this topic requires further investigation.

\section{Spider, true bug and ant communities on the roofs}

Spider communities were dominated by one common and highly dispersive pioneer species, and the number of species per roof was typically low (most roofs had $<5$ species). Also, the total number of spider species in our data (23 on 17 roofs) was low compared to studies on vegetated roofs in other climates and with different collection methods (Brenneisen and Hänggi 2006; Braaker et al. 2014; Bergeron et al. 2018). Spider communities did not differ statistically significantly between roof types. Yet, this seems to be explained by large differences in community composition within each roof type, rather than by similarity of communities on different types of roofs (see Fig. 2c). Moreover, the dominance of the highly dispersive Linyphiidae-family indicates that roofs are frequently re-colonized. Brenneisen and Hänggi (2006); Bergeron et al. (2018) also found Linyphiidae to be among the most frequent spiders, but not always dominant. Finally, the low abundance of Lycosidae (wolf spiders) was surprising, because they are typical of open habitats (Jocqué and Alderweireldt 2005) and also found on vegetated roofs (Brenneisen and Hänggi 2006; Braaker et al. 2014; Bergeron et al. 2018). It may be that our roofs were too small for hunting spiders requiring larger space compared to web-weavers, or that our collection method did not capture hunting spiders efficiently (see "Limitations of the study"). At least Bergeron et al. (2018) studied mostly roofs that were larger than ours (their roof size varied from $221 \mathrm{~m}^{2}$ to $825 \mathrm{~m}^{2}$ ), supporting our size-limitation explanation.

The true bug communities on succulent roofs were different from those on the two other roof types, which indicates that plant assemblages shape true bugs at the family level. According to trait data, true bug communities are characterized by herbivores that are associated with dry open habitats, dwell on the ground and/or in the herb layer and overwinter 
either as eggs or adults. We did not collect fully short-winged species, but found short-winged individuals of polymorphic species. Because short-winged individuals are unlikely to colonize roofs by themselves, they are probably offspring of long-winged individuals, or of short-winged individuals that arrived with roof materials. Almost all herbivorous true bugs were generalists (oligo- or polyphagous), which is typical for urban fauna (Knop 2016), but also supports the idea of Lundholm and Walker (2018) that vegetated roofs hardly match the requirements of highly specialized species unless specifically designed to do so. The number of true bug species per roof was low, but the total number of species was higher than reported in any previous studies. Yet, the comparability to previous studies is feeble as they are scarce and used various methods (suction sampling, Jones 2002; pitfalls, MacIvor and Lundholm; hand sampling, Madre et al. 2013).

Ant communities are usually species rich in urban areas (Santos 2016), with efficiently dispersing pioneer species and habitat generalists overrepresented as compared to rural areas (Vepsäläinen et al. 2008). The two species found on our study roofs, L. niger and M. rubra, are indeed generalists and also the most common species in the Helsinki area, and common in other European cities as well (Vepsäläinen et al. 2008). The observed increase in ant abundance with substrate depth and dead plant material is logical, because both species nest underground (Collingwood 1979), and litter helps the soil to hold moisture, making nest excavation easier. Ant species richness has been suggested to indicate the ease of colonization of new areas in urban environments (Yamaguchi 2004), the low number of species here pointing towards low accessibility.

\section{Impact of roof characteristics on individually analyzed taxa}

Results of the GLMMs supported only few of the hypothesized patterns but suggested other effects of roof characteristics on arthropods. The positive response to dead plant material was in line with the literature: litter creates shelter and positively affects predators by increasing prey abundances (Bultman and Uetz 1982). In contrast to Kyrö et al. (2018), roof age was unimportant in shaping arthropod abundance and it had both positive and negative effects when retained in the final models. Age was correlated with grass cover $(r=0.88)$ and because the effect of grass was mainly negative, it is likely that an increase in grass cover on older roofs decreases abundances of most arthropod taxa. Thus, roof age itself does not seem to affect arthropod abundance, but it has indirect effects via changes in vegetation.

Contrary to our hypothesis and previous findings with negative (Madre et al. 2013; MacIvor 2016) or varying effects (Kyrö et al. 2018) of roof height on the abundance of arthropods, our results support a positive effect of height on abundance. We found no effect of height on species richness, while previously height has been found to have positive, yet weak, effects on richness (Blank et al. 2017, based on Kadas 2006 data). Blank et al. (2017) suggested that weak and varying height effects are explained by low number of replicates and that positive height effect on richness is likely to be related with correlations between height and other roof variables, particularly roof size. In our data, height showed low collinearity $(\mathrm{VIF}<3)$ with other continuous variables and height frequently remained in the final models for arthropod abundance. The highest roof in our data was $11 \mathrm{~m}$, which is low compared with most previous studies (reviewed in Blank et al. 2017). Thus, the positive height-abundance connection we found may not hold on very high roofs. However, current evidence indicates that height does not limit the value of roof environments for a majority of arthropods that are able to colonize roofs. The mostly positive response to roof height could be related to decreased competition or predation on high roofs, but further studies are needed to be able to assess the role of biotic interactions on vegetated roofs.

The effect of roof size on arthropod abundances appears to vary (Madre et al. 2013; Ksiazek-Mikenas et al. 2018; Kyrö et al. 2018), and even though we found a positive size effect on true bug diversity, size does not seem to be important in explaining arthropod diversity on vegetated roofs in general (Madre et al. 2013; Braaker et al. 2014, 2017). A likely explanation is the small-island-effect (SIE), where species richness varies independently of patch area up to a certain minimum threshold value (Lomolino 2000). Even the largest roofs (350 $\mathrm{m}^{2}$ in our data) are below the estimated threshold for SIE for invertebrates (Wang et al. 2018).

We showed that arthropod communities differ between succulent, succulent-meadow and meadow roofs. Though we found no effect of the number of plant species on arthropod species richness, the ordinations still suggested that plant diversity had a community level impact on arthropods. Spiders, beetles and some true bugs showed negative abundance responses implying that they are more abundant on plant species-poor succulent roofs than species-rich meadow roofs. A positive relationship between succulent cover and arthropod abundance was also shown by Kadas (2006) comparing succulent and brown roofs in London. The vegetation on brown roofs relies on spontaneous colonization and the seed bank in the substrate, and they are expected to have a diverse vegetation. Kadas (2006) explained the result by the correlation of vegetation type and roof age (brown roofs were only one year old while the age of succulent roofs varied). However, our finding cannot be explained the same way, as many of our succulent roofs were younger than our meadow roofs, yet all roofs were at least three years old.

Finally, our hypothesis that roof size and height are more important to predatory arthropods than herbivores, was supported by the ordinations, where spider communities (the only 
fully predatory group in our data) were shaped by both vegetation characteristics and roof size and height at the family level, whereas (mainly herbivorous) true bug communities were only shaped by vegetation characteristics. However, the GLMMs did not support this hypothesis as, on one hand, vegetation variables were important also in shaping spider abundances and, on the other hand, true bug abundances were shaped by both vegetation characteristics and roof height.

\section{Limitations of the study}

Our study is among the first to vacuum sample arthropods on vegetated roofs. Thus, differences in our data compared to previous studies can partially be explained by the sampling method. The advantage of vacuum sampling is that substrate depth does not limit the selection of roofs, as it does for pitfall trapping. D-vac efficiently captures small, ground-dwelling and epiphytic arthropods, but is not optimal to collect large and heavy species or those that hide in the ground or under stones, such as Lycosidae spiders (Mommertz et al. 1996; Doxon et al. 2011; Standen 2000). It also only gives a snapshot of the fauna, while the air current, accompanied with loud engine noise, likely affects capture.

\section{Conclusions}

Arthropod communities on vegetated roofs are characterized by dispersive generalist feeders that are adapted to dry open habitats or are habitat generalists. These characteristics indicate that both stochastic dispersal and deterministic nichebased processes shape the roof communities (Leibold and McPeek 2006; Pandit et al. 2009). The variety of succulentmeadow roofs studied here yielded rather low numbers of species of ants and spiders and did not appear to support established populations of rare species, yet they are used by some habitat specialists associated with dry conditions. Thus, these kinds of vegetated roofs have potential to contribute to conservation of arthropod fauna of dry open habitats, but in their current form, their benefits for rare natives seem low.

The varying responses of different taxa to roof characteristics make recommendations for an optimal roof design challenging. Roof size appears to be of minor importance and some taxa benefit from increase in roof height. Thus, also small and high roofs contribute to biodiversity. Because responses to vegetation characteristics differ between arthropod taxa, increasing habitat diversity by creating diverse vegetation that includes forbs, grasses and succulents, instead of planting roofs with mostly succulents, will improve the habitat value of vegetated roofs. Also, as most arthropods responded negatively to grass cover, creating space for forbs and succulents on grass dominated roofs may enhance the value of these roofs as arthropod habitats. Finally, as we pointed out that there is a risk of introducing non-native fauna with imported vegetation, we recommend the use of locally produced plant and soil material.

Acknowledgements We thank the University of Helsinki Research Foundation, Finnish Cultural Foundation, Kone Foundation, Maj ja Tor Nessling Foundation, EFOP-3.6.3-VEKOP-16-2017-00008 project and European Social Fund for funding this research. We are grateful to Henri Järvisalo for assisting in fieldwork, and Giulia Cappelletto and Isabella Chesca Jeronimo for their contribution to sorting the arthropod material, and to Ilpo Mannerkoski for expert knowledge on the Finnish true bug fauna.

Funding Information Open access funding provided by University of Helsinki including Helsinki University Central Hospital.

Open Access This article is licensed under a Creative Commons Attribution 4.0 International License, which permits use, sharing, adaptation, distribution and reproduction in any medium or format, as long as you give appropriate credit to the original author(s) and the source, provide a link to the Creative Commons licence, and indicate if changes were made. The images or other third party material in this article are included in the article's Creative Commons licence, unless indicated otherwise in a credit line to the material. If material is not included in the article's Creative Commons licence and your intended use is not permitted by statutory regulation or exceeds the permitted use, you will need to obtain permission directly from the copyright holder. To view a copy of this licence, visit http://creativecommons.org/licenses/by/4.0/.

\section{References}

Amrhein et al (2017) The earth is flat ( $p>0.05)$ : significance thresholds and the crisis of unreplicable research. PeerJ 5:e3544. https://doi. org 10.7717 peerj.3544

Appelt M, Poethke HJ (1997) Metapopulation dynamics in a regional population of the blue-winged grasshopper (Oedipoda caerulescens; Linnaeus, 1758). J Insect Conserv 1:205-214. https://doi.org/10. 1023/A:1018468017604

Bates D, Mächler M, Bolker B, Walker S (2015) Fitting Linear MixedEffects Models Using lme4. J Stat Softw 67. https://doi.org/10. 18637/jss.v067.i01

Bergeron JAC, Pinzon J, Spence JR (2018) Carabid and spider population dynamics on urban green roofs. Zoosymposia 12:69. https://doi.org/ 10.11646/zoosymposia.12.1.8

Blank L, Vasl A, Schindler BY et al (2017) Horizontal and vertical island biogeography of arthropods on green roofs: a review. Urban Ecosyst. https://doi.org/10.1007/s11252-016-0639-9

Bolger DT, Suarez AV, Crooks KR et al (2000) Arthropods in urban habitat fragments in Southern California: area, age and edge effects. Ecol Appl 10:1230-1248. https://doi.org/10.1890/1051-0761(2000) 010[1230:AIUHFI]2.0.CO;2

Braaker S, Ghazoul J, Obrist MK, Moretti M (2014) Habitat connectivity shapes urban arthropod communities: the key role of green roofs. Ecology 95:1010-1021. https://doi.org/10.1890/13-0705.1

Braaker S, Obrist MK, Ghazoul J, Moretti M (2017) Habitat connectivity and local conditions shape taxonomic and functional diversity of arthropods on green roofs. J Anim Ecol 86:521-531. https://doi. org/10.1111/1365-2656.12648

Brenneisen S (2006) Space for Urban Wildlife: Designing Green Roofs as Habitats in Switzerland. Urban habitats 4:27-36

Brenneisen S, Hänggi A (2006) Begrünte Dächer-ökofaunistische Charakterisierung eines neuen Habitattyps in Siedlungsgebieten 
anhand eines Vergleichs der Spinnenfauna von Dachbegrünungen mit naturschutzrelevanten Bahnarealen in Basel (Schweiz). Mitteilungen der Naturforschenden Gesellschaften beider Basel 9: 99-122

Bultman TL, Uetz GW (1982) Abundance and community structure of forest floor spiders following litter manipulation. Oecologia 55:34 41. https://doi.org/10.1007/BF00386715

Cadotte MW, Carscadden K, Mirotchnick N (2011) Beyond species: functional diversity and the maintenance of ecological processes and services: functional diversity in ecology and conservation. J Appl Ecol 48:1079-1087. https://doi.org/10.1111/j.1365-2664. 2011.02048.x

Colla S, Willis E, Packer L (2009) Can green roofs provide habitat for urban bees (Hymenoptera: Apidae)? Cities Environ 2:1-12

Collingwood CA (1979) The Formicidae (Hymenoptera) of Fennoscandia and Denmark. Fauna Entomologica Scandinavia 8: 9-156

Dearborn DC, Kark S (2010) Motivations for Conserving Urban Biodiversity. Conserv Biol 24:432-440. https://doi.org/10.1111/j. 1523-1739.2009.01328.x

Dietick EJ, Schlinger EI, Van Den Bosch R (1959) A new method for sampling arthropods using a suction collecting machine and modified Berlese funnel separator1. J Econ Entomol 52:1085-1091. https://doi.org/10.1093/jee/52.6.1085

Doxon ED, Davis CA, Fuhlendorf SD (2011) Comparison of two methods for sampling invertebrates: vacuum and sweep-net sampling: methods of sampling invertebrates. J Field Ornithol 82:60 67. https://doi.org/10.1111/j.1557-9263.2010.00308.x

Dray S, Legendre P (2008) Testing the species traits-environment relationships: the fourth-corner problem revisited. Ecology 89:3400 3412. https://doi.org/10.1890/08-0349.1

Dray S, Choler P, Dolédec S et al (2014) Combining the fourth-corner and the RLQ methods for assessing trait responses to environmental variation. Ecology 95:14-21. https://doi.org/10.1890/13-0196.1

European Commission, Directorate-General for Research and Innovation (2015) Towards an EU research and innovation policy agenda for nature-based solutions \& re-naturing cities: final report of the Horizon 2020 expert group on "Nature-based solutions and renaturing cities": (full version). Publications Office of the European Union, Luxembourg

Francis RA, Lorimer J (2011) Urban reconciliation ecology: the potential of living roofs and walls. J Environ Manag 92:1429-1437. https:// doi.org/10.1016/j.jenvman.2011.01.012

Gabrych M, Kotze DJ, Lehvävirta S (2016) Substrate depth and roof age strongly affect plant abundances on sedum-moss and meadow green roofs in Helsinki, Finland. Ecol Eng 86:95-104. https://doi.org/10. 1016/j.ecoleng.2015.10.022

Gagic V, Bartomeus I, Jonsson T et al (2015) Functional identity and diversity of animals predict ecosystem functioning better than species-based indices. Proc R Soc B Biol Sci 282:20142620. https://doi.org/10.1098/rspb.2014.2620

Grimm NB, Faeth SH, Golubiewski NE et al (2008) Global change and the ecology of cities. Science 319:756-760. https://doi.org/10.1126/ science. 1150195

Harrison XA (2014) Using observation-level random effects to model overdispersion in count data in ecology and evolution. PeerJ 2: e616. https://doi.org/10.7717/peerj.616

Hyvärinen E, Juslén A, Kemppainen E et al (2019) The 2019 Red List of Finnish Species. Suomen ympäristökeskus, Ympäristöministeriö

Jones RA (2002) Tecticolous Invertebrates: A preliminary investigation of the invertebrate fauna on green roofs in urban London. Br Wildl 12:91-98

Kadas G (2006) Rare invertebrates colonizing green roofs in London. Urban Habitats 4:66-86

Kenis M, Rabitsch W, Auger-Rozenberg M-A, Roques A (2007) How can alien species inventories and interception data help us prevent insect invasions? Bull Entomol Res 97:489-502. https://doi.org/10. 1017/S0007485307005184

Knop E (2016) Biotic homogenization of three insect groups due to urbanization. Glob Change Biol 22:228-236. https://doi.org/10.1111/ gcb.13091

Kotze DJ, O'Hara RB, Lehvävirta S (2012) Dealing with varying detection probability, unequal sample sizes and clumped distributions in count data. PLOS ONE 7:e40923. https://doi.org/10.1371/journal. pone.0040923

Kotze DJ, Kuoppamäki K, Niemikapee J, et al (2020) A revised terminology for vegetated rooftops based on function and vegetation. Urban For Urban Gree 49:126644. https://doi.org/10.1016/j.ufug. 2020.126644

Kruess A, Tscharntke T (1994) Habitat fragmentation, species loss, and biological control. Science 264:1581-1584. https://doi.org/10.1126/ science.264.5165.1581

Ksiazek K, Fant J, Skogen K (2012) An assessment of pollen limitation on Chicago green roofs. Landsc Urban Plan 107:401-408. https:// doi.org/10.1016/j.landurbplan.2012.07.008

Ksiazek-Mikenas K, Herrmann J, Menke S, Köhler M (2018) If you build it, will they come? Plant and arthropod diversity on urban green roofs over time. Urban Naturalist Special issue 1:52-72

Kutschbach-Brohl L, Washburn BE, Bernhardt GE et al (2010) Arthropods of a semi-natural grassland in an urban environment: the John F. Kennedy International Airport, New York. J Insect Conserv 14:347-358. https://doi.org/10.1007/s10841-010-9264-8

Kyrö K, Brenneisen S, Kotze DJ et al (2018) Local habitat characteristics have a stronger effect than the surrounding urban landscape on beetle communities on green roofs. Urban For Urban Green 29:122130. https://doi.org/10.1016/j.ufug.2017.11.009

Leibold MA, Holyoak M, Mouquet N et al (2004) The metacommunity concept: a framework for multi-scale community ecology: the metacommunity concept. Ecol Lett 7:601-613. https://doi.org/10. 1111/j.1461-0248.2004.00608.x

Leibold MA, McPeek MA (2006) Coexistence of the niche and neutral perspectives in community ecoloy. Ecology 87:1399-1410. https:// doi.org/10.1890/0012-9658(2006)87[1399:COTNAN]2.0.CO;2

Linnavuori R (2007) Studies on the Miridae (Heteroptera) of Gilan and the adjacent provinces in northern Iran. Acta Entomol Musei Natl Pragae 47:17-56

Lomolino MV (2000) Ecology's most general, yet protean 1 pattern: the species-area relationship. J Biogeogr 27:17-26. https://doi.org/10. 1046/j.1365-2699.2000.00377.x

Lundholm JT, Walker W (2018) Evaluating the habitat template approach applied to green roofs. Urban Naturalist S1:39-51

MacArthur RH, Wilson EO (1967, reprinted 2001) The theory of island biogeography. Princeton University Press, Princeton

MacIvor JS (2016) Building height matters: nesting activity of bees and wasps on vegetated roofs. Israel J Ecol Evol 62:88-96. https://doi. org/10.1080/15659801.2015.1052635

MacIvor JS, Lundholm J (2011) Insect species composition and diversity on intensive green roofs and adjacent level-ground habitats. Urban Ecosystems 14:225-241. https://doi.org/10.1007/s11252-010-01490

Madre F, Vergnes A, Machon N, Clergeau P (2013) A comparison of 3 types of green roof as habitats for arthropods. Ecol Eng 57:109-117. https://doi.org/10.1016/j.ecoleng.2013.04.029

Madre F, Vergnes A, Machon N, Clergeau P (2014) Green roofs as habitats for wild plant species in urban landscapes: first insights from a large-scale sampling. Landsc Urban Plan 122:100-107. https://doi. org/10.1016/j.landurbplan.2013.11.012

Maes J, Jacobs S (2017) Nature-based solutions for Europe's sustainable development: Europe's sustainable development. Conserv Lett 10: 121-124. https://doi.org/10.1111/conl.12216

McCune B, Grace JB, Urban DL (2002) Analysis of ecological communities, 2nd printing. MjM Software Design, Gleneden Beach 
McDonald RI, Colbert M, Hamann M et al (2018) Report: nature in the Urban Century, The Nature Conservancy, $78 \mathrm{p}$

McGill B, Enquist B, Weiher E, Westoby M (2006) Rebuilding community ecology from functional traits. Trends Ecol Evol 21:178-185. https://doi.org/10.1016/j.tree.2006.02.002

McKinney ML (2002) Urbanization, biodiversity, and conservation. BioScience 52:883. https://doi.org/10.1641/0006-3568(2002) 052[0883:UBAC]2.0.CO;2

Mommertz S, Schauer C, Kösters N et al (1996) A comparison of D-Vac suction, fenced and unfenced pitfall trap sampling of epigeal arthropods in agroecosystems. Ann Zool Fenn 33:117-124

Nurmi V, Votsis A, Perrels A, Lehvävirta S (2016) Green roof cost-benefit analysis: special emphasis on scenic benefits. J Benefit-Cost Anal 7: 488-522. https://doi.org/10.1017/bca.2016.18

Oksanen J, Blanchet G, Friendly M et al (2018) vegan: Community Ecology Package. R package version 2.5-2

Páll-Gergely B, Kyrö K, Lehvävirta S, Vilisics F (2014) Green roofs provide habitat for the rare snail (Mollusca, Gastropoda) species Pseudotrichia rubiginosa and Succinella oblonga in Finland. Memoranda Societatis Pro Fauna Et Flora Fennica 90:13-15

Pandit SN, Kolasa J, Cottenie K (2009) Contrasts between habitat generalists and specialists: an empirical extension to the basic metacommunity framework. Ecology 90:2253-2262. https://doi. org $/ 10.1890 / 08-0851.1$

Pétremand G, Chittaro Y, Braaker S et al (2018) Ground beetle (Coleoptera: Carabidae) communities on green roofs in Switzerland: synthesis and perspectives. Urban Ecosystems 21: 119-132. https://doi.org/10.1007/s11252-017-0697-7

R Core Team (2018) R: A language and environment for statistical computing. R Foundation for Statistical Computing, Vienna

Rosenzweig ML (1995) Species diversity in space and time. Cambridge University Press, Cambridge

Salman I, Blaustein L (2018) Vegetation cover drives arthropod communities in Mediterranean/Subtropical green roof habitats. Sustainability 10:4209. https://doi.org/10.3390/su10114209

Santos MN (2016) Research on urban ants: approaches and gaps. Insect Soc 63:359-371. https://doi.org/10.1007/s00040-016-0483-1
Saukkonen T (2011) Helsingin kaupungin luonnonhoidon linjaus. Helsingin kaupungin rakennusviraston julkaisut 14

Schielzeth H (2010) Simple means to improve the interpretability of regression coefficients: interpretation of regression coefficients. Methods Ecol Evol 1:103-113. https://doi.org/10.1111/j.2041210X.2010.00012.x

Schindler BY, Griffith AB, Jones KN (2011) Factors influencing arthropod diversity on green roofs. Cities Environ 4:1-20

Seto KC, Guneralp B, Hutyra LR (2012) Global forecasts of urban expansion to 2030 and direct impacts on biodiversity and carbon pools. Proc Natl Acad Sci 109:16083-16088. https://doi.org/10.1073/pnas. 1211658109

Standen V (2000) The adequacy of collecting techniques for estimating species richness of grassland invertebrates. J Appl Ecol 37:884-893. https://doi.org/10.1046/j.1365-2664.2000.00532.x

Tonietto R, Fant J, Ascher J et al (2011) A comparison of bee communities of Chicago green roofs, parks and prairies. Landsc Urban Plan 103:102-108. https://doi.org/10.1016/j.landurbplan.2011.07.004

van Noordwijk CGE (Toos), Verberk WCEP, Turin H et al (2015) Species-area relationships are modulated by trophic rank, habitat affinity, and dispersal ability. Ecology 96:518-531. https://doi.org/ 10.1890/14-0082.1

Vepsäläinen K, Ikonen H, Koivula MJ (2008) The structure of ant assemblages in an urban area of Helsinki, Southern Finland. Ann Zool Fenn 45:109-127

Wang Y, Chen C, Millien V (2018) A global synthesis of the small-island effect in habitat islands. Proc R Soc B Biol Sci 285. https://doi.org/ 10.1098/rspb.2018.1868

Williams NSG, Lundholm J, Scott MacIvor J (2014) FORUM: do green roofs help urban biodiversity conservation? J Appl Ecol 51:16431649. https://doi.org/10.1111/1365-2664.12333

Yamaguchi T (2004) Influence of urbanization on ant distribution in parks of Tokyo and Chiba City, Japan I. Analysis of ant species richness. Ecol Res 19:209-216. https://doi.org/10.1111/j.1440-1703.2003. 00625. $\mathrm{x}$

Zuur AF, Ieno EN, Elphick CS (2010) A protocol for data exploration to avoid common statistical problems: data exploration. Methods Ecol Evol 1:3-14. https://doi.org/10.1111/j.2041-210X.2009.00001.x 